\title{
Digitalizing a New Higher Education Degree Course to Best Satisfy Students: A Proposal of Best Practices
}

\author{
Pablo Ruiz-Palomino \\ University of Castilla-La Mancha
}

\author{
Ricardo Martínez-Cañas \\ University of Castilla-La Mancha \\ Jorge Linuesa-Langreo \\ University of Castilla-La Mancha
}

\begin{abstract}
Digitalization is a complex challenge for many higher education institutions worldwide given that the new trend for best performance is to draw on ICTs to provide quality, interactive teaching to promote the highest student satisfaction. In this sense, most universities, in their digitalization processes, have opted for the Moodle learning platform, as it allows them to manage different digitized content (text, videos, evaluations, etc.), thus providing staff with a powerful tool to successfully implement the teaching-learning process. The purpose of this study is to determine, from the student perspective, the aspects universities should focus on when making the decision to digitalize a new degree course. To this end, qualitative interviews and quantitative surveys were administered to a representative sample of students to gather information on the current state of digitalization of the degree course they were studying (a Degree in Tourism recently included among the courses offered by a Spanish University).
\end{abstract}

Keywords: digitalization, teaching-learning process, ICTs, higher education, student satisfaction, Moodle

\section{INTRODUCTION}

The teaching-learning processes of higher education institutions are experiencing major digital transformations as today's students mainly communicate and learn through the use of ICT (ZempoaltecaDurán et al., 2017). For more than a decade, the university digitalization process has been tackling the incorporation of technologies in classrooms; new equipment, new infrastructures, and new software are increasingly being implemented in European Higher Education institutions, with the aim of approaching the new educational paradigm proposed by the European Higher Education Area (EHEA), inspired by the demands of the new knowledge society (García-Peñalvo, 2021). This transformation process has gained momentum recently with the lockdown measures implemented during 2020 to contain the spread of the COVID-19 virus, which has resulted in more than 1,500 million people around the world receiving different types of education through ICT (UNESCO, 2020). 
ICT represents a valuable support for teaching and learning that higher education institutions cannot ignore, given that Higher Education students are $\mathrm{Y}$ and $\mathrm{Z}$ generation students and digital natives, and the use of ICTs in the classroom is essential to prepare them for their future career. However, in digitalizing, university IT departments need instructions on how and when to digitalize. The array of options that can be used is extensive, typically ranging from digitizing existing products/new education products (e.g., video lectures, digital texts, easy and quick access to literature, software and other material or resources) to digitizing common activities such as examinations, study planning, teacher allocation or scheduling, among others.

The vast majority of Spanish universities have focused their digitalization strategy by integrating it into Moodle as a learning management system. This is because, compared to other applications and web systems on the market, it is more efficient and viable for didactic use (Sánchez-Santamaría \& Calvo, 2012). The Moodle learning platform is the most powerful tool currently available to teachers to create and manage their courses through the network (Ros-Martínez-de la Hidalga, 2008). It allows different educational content (text, images, videos, presentations, etc.) to be managed, facilitates communication with, and among, students, and finally, can be used to manage evaluation of the different learning tasks (Lázaro, 2010). At a pedagogical level, this platform provides teachers with great autonomy of use, allowing them to include all kinds of didactic resources available to students in the web application, as well as subsequent control and monitoring of the work carried out by students in the virtual classroom (Rivadulla-López, 2015). Importantly, the Moodle platform is also useful for students; it allows them to have greater autonomy in terms of pace of learning and study. Therefore, the satisfaction at all levels and profiles of those who manage this platform can be considered very high and beneficial for everyone involved (Lázaro, 2010).

Despite the positive effects of digitalization processes and the use of learning platforms such as Moodle implemented by Spanish universities, most studies have been conducted from an institutional perspective (Lázaro, 2010; Sánchez-Santamaría and Calvo, 2012), relegating one of the fundamental pillars of the teaching-learning process to second place, that is, the student. Therefore, our study collects information on the digital experience of university students with a twofold objective. Firstly, this study will analyse three fundamental variables concerning the use of the Moodle learning platform, namely, degree of interaction, level of satisfaction, and influence of the use of Moodle on the academic result. Secondly, we will also investigate the aspects students consider universities should improve to optimize the digitalization process of a degree course recently implemented in a Higher Education institution located in the central area of Spain.

\section{METHODOLOGY}

This study is based on a mixed methodology through which we use and analyse both quantitative and qualitative data (Molina-Azorín \& Fetters, 2019). In a first phase, we collected quantitative data through a survey administered to 51 students enrolled on a degree course in Tourism -recently implemented in a Spanish university. Of these, 22 were women (43.14\%) and 29 were men (56.86\%) The questionnaire uses 5 -point response format ( $1=$ "strongly disagree," $5=$ "strongly agree") to gather information on three fundamental variables related to the use and experience of the Moodle learning platform, as described below.

- Interaction with Moodle. We created this variable through the perceived ease of use dimension proposed by Lowry et al. (2013), and the dimensions of information quality, system quality and Moodle communicativeness used by Damnjanovic et al. (2015) in their scale.

- Satisfaction with Moodle. The reliable 4-item scale designed by Damnjanovic et al. (2015) was administered to the students, who, in their responses to the items, gave information concerning their level of satisfaction with the use of Moodle.

- Moodle's impact on academic performance. We applied the reliable 4-item scale used by Damnjanovic et al. (2015) to rate the impact of Moodle on the students' academic performance.

Along with these two fundamental variables, the survey included other questions related to the level of digitalization of the students or their predisposition towards new technologies. Specifically, students were 
asked to report on the following aspects: a) whether they had an Internet connection at their habitual residence; b) whether they had their own computer or laptop; c) the type of electronic device they typically used; d) whether they had received training in ICT and on the Moodle platform; e) the type of operating system they used; and f) their preferred Internet browser.

Finally, the quantitative stage is completed with a second qualitative phase through semi-structured interviews conducted with participants in our study (51 students enrolled in a Tourism degree course at a university in central Spain). They were given the opportunity to list aspects they considered should be reinforced or included in the design of the teaching-learning process with the aim of optimizing the digitalization process of the degree they were studying and through which the teaching-learning process of the degree could be enhanced.

\section{RESULTS}

The analysis of the data from the questionnaires yielded the following results. Regarding the basic aspects of the students' digitalization, the results revealed that the participants in this study generally had a good level of digitalization. Indeed, according to the results, it should be noted that 49 of the 51 students surveyed (96.08\%) reported having an internet connection in their habitual residence. Interestingly, 100\% of the participants had their own computer. Specifically, the vast majority had a laptop $(92.16 \%)$, with a tablet being the second most commonly used device (5.89\%). Regarding their training in both ICT and the Moodle platform, $60.78 \%$ of the students reported having received ICT training and $66.67 \%$ had been trained in the use of the Moodle platform.

Regarding the operating systems most commonly used by the participants in our study, Figure 1 shows that the Microsoft Windows operating system was clearly the most popular (72.55\% of the students used this system). Microsoft Windows was the most widely used operating system due to its easy handling and general use in most computer programs. Another widely used operating system was Mac OS (25.49\%), and the least used operating system was Linux (1.96\%).

FIGURE 1

\section{OPERATING SYSTEMS USED BY STUDENTS}

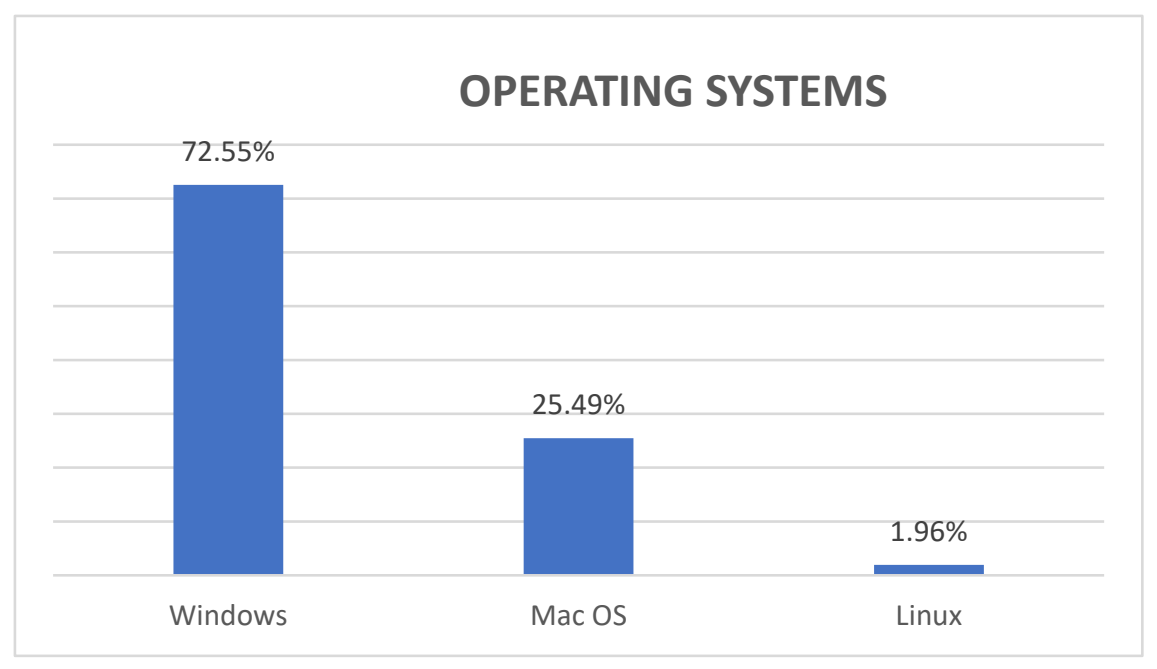

As regards the Internet browsers used by our participants, Figure 2 reveals that Google Chrome was the most commonly used search engine. Indeed, Figure 2 shows that Google Chrome, as the first choice for $74.51 \%$ of the university students, stands out in first place. This finding is unsurprising as Google Chrome is commonly linked to other applications (e.g., Gmail, Google Scholar, Google Drive, etc.), that university 
students need to effectively do the tasks they are assigned. The least widely used Internet browsers were Safari (19.61\%) and Internet Explorer (5.88\%).

Once we had analysed different aspects concerning the level and type of digitalization of the students participating in our investigation, we examined aspects related to our main study variables. Table 1 shows important information about the degree of our participants' interaction with the Moodle platform. Specifically, Table 1 shows the following dimensions of this degree of interaction with the Moodle platform: a) perceived ease of use, b) information quality, c) system quality, and d) Moodle communicativeness.

FIGURE 2

INTERNET BROWSERS USED BY STUDENTS

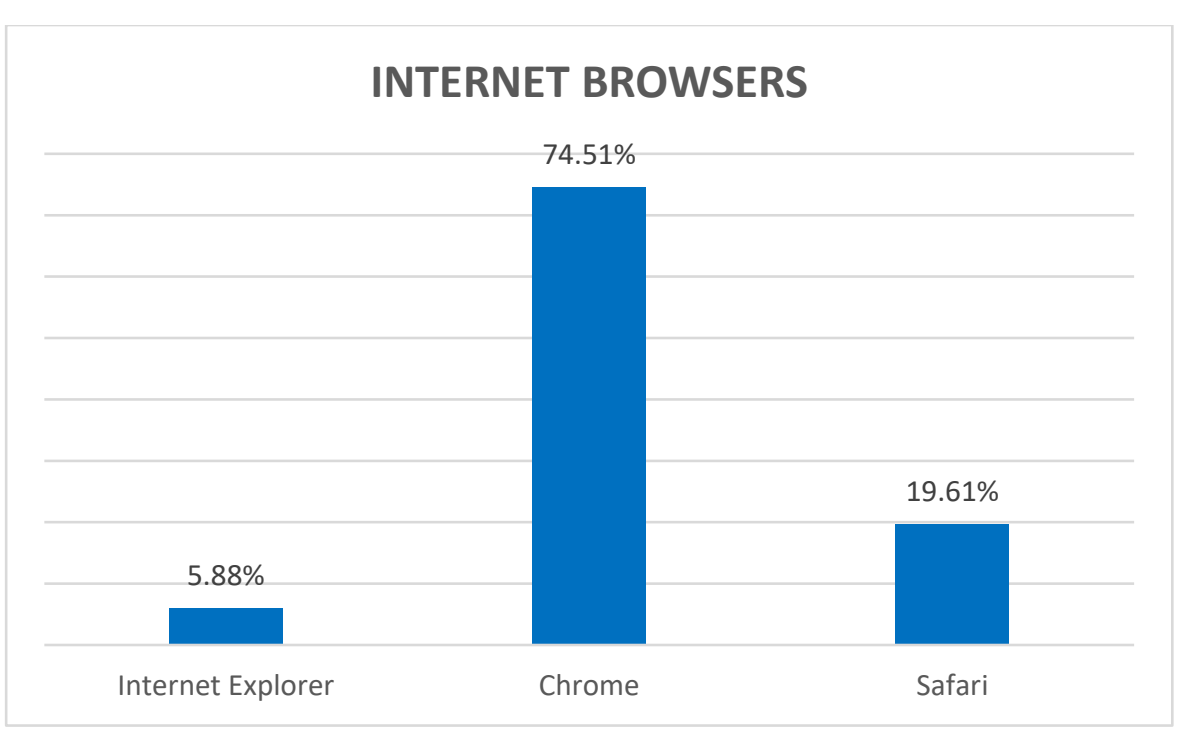

TABLE 1

STUDENT INTERACTION WITH MOODLE

\begin{tabular}{l|c|c}
\hline \hline PERCEIVED EASE OF USE & M & SD \\
\hline My interaction with Moodle was clear and understandable & 4.01 & 0.77 \\
\hline Interaction with Moodle did not require much mental effort & 4.00 & 0.94 \\
\hline I found Moodle easy to use & 4.16 & 0.95 \\
\hline I found it easy to do I wanted to do in Moodle & 3.90 & 0.83 \\
\hline Learning to work with Moodle was easy & 3.99 & 0.83 \\
\hline Doing what I wanted to do with Moodle was simple & 3.88 & 1.01 \\
\hline I found Moodle easy to use & 4.16 & 0.92 \\
\hline INFORMATION QUALITY & $\mathbf{M}$ & SD \\
\hline $\begin{array}{l}\text { This technological learning platform provides me with highly valuable } \\
\text { information about my courses, studies ... }\end{array}$ & 3.84 & 0.99 \\
\hline $\begin{array}{l}\text { This technological platform provides me with updated and useful information for } \\
\text { my studies }\end{array}$ & 3.87 & 0.92 \\
\hline SYSTEM QUALITY & $\mathbf{M}$ & SD \\
\hline I trust the security of the system & 3.33 & 1.24 \\
\hline The Moodle tool is easy to understand & 4.08 & 0.82 \\
\hline When I use the Moodle tool, I do my work correctly & 4.04 & 0.77 \\
\hline
\end{tabular}




\begin{tabular}{l|c|c}
\hline MOODLE COMMUNICATIVENESS & M & SD \\
\hline The Moodle tool makes it easier to discuss aspects of the course with the teacher & 2.38 & 1.21 \\
\hline The Moodle tool makes it easy to share new knowledge with other users & 2.48 & 1.29 \\
\hline The Moodle tool makes it easier to gain access to other users' knowledge & 2.97 & 1.26 \\
\hline The Moodle tool makes discussion with other course students easier & 2.92 & 1.29 \\
\hline
\end{tabular}

Notes: $M$ and SD refer to mean and standard deviation, respectively.

As Table 1 reveals, all the items from the dimension of perceived ease of use present high mean values, ranging between 3.88 ("Doing what I wanted to do with Moodle was simple") and 4.16 ("I found Moodle easy to use"). Second, with regards to the information quality dimension, the results shown in Table 1 reveal high values in both items: "This technological learning platform provides me with highly valuable information about my courses, studies ..." (Mean = 3.84) and "This technological platform provides me with updated and useful information for my studies" (Mean $=3.87$ ). Third, the system quality dimension, in line with the previous dimensions, presented high values for its two items: "This Moodle tool is easy to understand" (Mean = 4.08) and "When I use the Moodle tool, I do my work correctly" (Mean = 4.04). Finally, it should be noted that the Moodle communicativeness dimension that presents lower average values than the rest of the dimensions. This is especially true in the following items: "The Moodle tool makes it easier to discuss aspects of the course with the teacher" (Mean = 2.38), and "The Moodle tool makes it easy to share new knowledge with other users" $($ Mean $=2.48)$, both of which are below the mean of the scale $($ Mean $=2.5)$.

TABLE 2

STUDENT SATISFACTION WITH MOODLE

\begin{tabular}{l|c|c}
\hline \hline STUDENT SATISFACTION WITH MOODLE & M & SD \\
\hline In general, using this platform and receiving online training satisfies me enormously & 3.89 & 0.99 \\
\hline If asked, I would recommend Moodle and this digitalized form of being taught as ideal & 3.88 & 1.03 \\
\hline I plan to continue using Moodle in the future & 3.59 & 0.98 \\
\hline I will try to continue using Moodle in the future & 3.61 & 1.06 \\
\hline \hline
\end{tabular}

Notes: $M$ and $S D$ refer to mean and standard deviation, respectively.

In terms of the level of satisfaction experienced by the students, our results reveal that Moodle's functionalities are considered highly satisfactory by university students. Table 2, for example, shows high values in the items of the variable "student satisfaction with Moodle" included in our survey. The four items of the construct show mean values above 3.5, highlighting the following: "In general, using this platform and receiving online training satisfies me enormously" (Mean $=3.89)$ and "If asked, I would recommend Moodle and this digitalized way of being taught as ideal" (Mean = 3.88). Thus, Moodle appears to be a learning management system that generates a high degree of satisfaction among the participants in our research.

With regard to the information on the influence of the use of Moodle on the students' academic performance, our findings highlight the positive influence of this learning management system. In the three items used to assess this aspect of the management system under study, the students show values above the mean of the scale (see Table 3). For example, in the item: "Using Moodle tends to improve my grades in the subject in which I use it the most", the mean value was 3.39. In the item, "Using this technology platform has improved my overall learning performance", the mean value was of 3.35. Finally, in the item "The application of e-learning through Moodle has helped me to independently continue learning about the Internet", the mean value was 3.12 . 
TABLE 3

IMPACT OF MOODLE ON ACADEMIC PERFORMANCE

\begin{tabular}{l|c|c}
\hline \hline IMPACT OF MOODLE ON ACADEMIC PERFORMANCE & M & SD \\
\hline $\begin{array}{l}\text { Using Moodle tends to improve my grades in the subject in which I use it the } \\
\text { most }\end{array}$ & 3.39 & 1.11 \\
\hline $\begin{array}{l}\text { Using this technology platform has improved my overall learning } \\
\text { performance }\end{array}$ & 3.35 & 1.16 \\
\hline $\begin{array}{l}\text { The application of e-learning through Moodle has helped me to independently } \\
\text { continue learning about the Internet }\end{array}$ & 3.12 & 1.21 \\
\hline
\end{tabular}

Note: $M$ and SD refer to mean and standard deviation, respectively.

The findings above described suggest that, as a management system, Moodle is greatly appreciated by students; it greatly satisfies them and is considered of considerable help in enhancing their academic attainment. Notwithstanding, the students also revealed that other aspects of digitalization could be implemented in the teaching-learning process followed in the degree in tourism. The qualitative part of our investigation, which consisted of semi-structured interviews with the Tourism students, revealed some important points that university managers should take into account. The students who participated in the study offered several ideas to improve the digitalization process of the degree they were studying (Tourism) and which can help other university managers in designing the digitalization strategies of the new degrees they to be implemented in the near future. Our results show that, as aspects that could be improved to better digitalize the new degree course in tourism, most of the students suggested: a) recording the lectures in the form of videos through Moodle, b) greater availability of the teacher through the Moodle platform; c) the use of Moodle to propose tests or exams through electronic devices, the computer or the laptop; d) more emphasis on the need for greater interaction between members of the Moodle platform to carry out assignments or practical aspects of the course; and finally e) more emphasis on training in digital skills at the beginning of the course through implementation of "zero courses", in which the new students enrolled in the degree course can be trained in digital skills.

\section{CONCLUSIONS}

Faced with the significant challenges of the digitalization process posed by the European Higher Education Area (EHEA), it is necessary to have tools that facilitate the teaching-learning process for both teachers and students. In this sense, the Moodle learning platform appears to be a safe option, supported by the results of our study. Its progressive and continuous implementation in most Spanish universities has been successful. However, the road is long and hard and the path to be followed is one of continuous adaptation to the current social reality. For this reason, the experience of our students offers highly valuable information. Through our study, the information we collected has allowed us, on the one hand, to confirm the advantages of using Moodle, as previous studies have shown (Lázaro, 2010; Umek et al., 2015), and has allowed us to highlight aspects that need to be improved and influenced to optimize the digitalization process in higher education institutions. Among the many aspects that must be addressed to successfully digitalize degree courses in higher education institutions are the following: 1) communicativeness that allows the discussion of aspects of the course with the teacher and other students, 2) training courses in digital skills to train both students and teachers in these competencies, and 3) the full development of all the possibilities offered by the Moodle platform (i.e., recordings of lectures on the subject as well as the use of Moodle platform to launch tests or exams, among other aspects).

Based on the information obtained in the study, there are important practical implications for managers of higher education institutions to better digitalize the degree courses provided by universities. Specifically, we consider that university managers should adapt and improve their digitalization strategies through two fundamental lines of action. A first line of action must be focused on enhancing and making the most of the 
multiple connectivity possibilities offered by the Moodle learning platform. For this, it is necessary to organize, mainly at the beginning of each academic year, various seminars, webinars or courses directed at both teachers and students. The design and realization of such seminars or webinars would be highly beneficial to help students and teachers to learn about the wide range of communication possibilities available via using Moodle and that can therefore be used throughout the academic year both inside and outside the classroom. A second line of action that managers of higher education institutions should implement concerns training initiatives in various ICT competencies. The better their expertise and ability in digital technologies, the easier it will be for both students and teachers to use ICT in the teaching-learning process. Thus, it seems to be important that numerous training initiatives in ICT competencies should be developed throughout the academic year, so that these initiatives can be helpful to complete the digital training of both teachers and students.

\section{ACKNOWLEDGEMENT}

The authors wish to thank the University of Castilla-La Mancha for the funding and help provided to carry out this paper. This paper is within the framework of a teaching innovation project with funding granted by the University of Castilla-La Mancha to the Faculty of Social Sciences of Cuenca ( $11^{\text {th }}$ call for Innovation and Teaching Improvement Projects University of Castilla-La Mancha 2019-2021).

A shortened version of this article is published in EDULEARN21 Proceedings.

\section{REFERENCES}

Damnjanovic, V., Jednak, S., \& Mijatovic, I. (2015). Factors affecting the effectiveness and use of Moodle: students' perception. Interactive Learning Environments, 23(4), 496-514.

García-Peñalvo, F.J. (2021). Estrategia institucional de digitalización para organizaciones educativas. PM4R Máster Professional: Gestión de Proyectos con orientación en Educación. https://doi.org/10.5281/zenodo.4717455

Lázaro, M.R.D. (2010). Moodle, una plataforma formativa con gran proyección en los nuevos modelos de enseñanza. DIM: Didáctica, Innovación y Multimedia, 19, 1-14.

Lowry, P.B. Gaskin, J., Twyman, N., Hammer, B., \& Roberts, T. (2013). Taking ‘fun and games' seriously: Proposing the hedonic-motivation system adoption model (HMSAM). Journal of the Association for Information Systems, 14(11), 617-671.

Molina-Azorín, J.F., \& Fetters, M.D. (2019). Building a Better World Through Mixed Methods Research. Journal of Mixed Methods Research, 13(3), 275-281.

Rivadulla-López, J.C. (2015). Concepciones de los estudiantes de Magisterio sobre Moodle. Revista de Estudios e Investigación en Psicología y Educación, 13, 68-72.

Ros-Martínez-de la Hidalga, I. (2008). Moodle, la plataforma para la enseñanza y organización escolar. Ikastorratza, e-Revista de Didáctica, 2, 3-12.

Sánchez-Santamaría, J., \& Calvo, S.M. (2012). Docencia universitaria con apoyo de entornos virtuales de aprendizaje (EVA). Digital Education Review, 21, 33-46.

Umek, L., Keržič, D., Aristovnik, A., \& Tomaževič, N. (2015). Analysis of selected aspects of students' performance and satisfaction in a Moodle-based e-learning system environment. Eurasia Journal of Mathematics, Science and Technology Education, 11(6), 1495-1505.

UNESCO. (2020). COVID-19 Impact on Education. Retrieved from https://bit.ly/2yJW4yy

Zempoalteca-Durán, B., Barragán-López, J.F., González-Martínez J., \& Guzmán-Flores, T. (2017). Formación en TIC y competencia digital en la docencia en instituciones públicas de educación superior. Apertura (Guadalajara, Jal.), 9(1), 80-96. 